\title{
WRITTEN CORRECTIVE FEEDBACK APPLIED BY ENGLISH TEACHER AT THE EIGHTH GRADE STUDENTS OF SMP NU PALANGKA RAYA
}

\author{
Umratul Janah \\ University of Palangkaraya \\ umratuljannaah@gmail.com \\ Wahyuningsih Usadiati \\ University of Palangkaraya \\ wahyuusadiati@edu.upr.ac.id \\ Ristati \\ University of Palangkaraya \\ Tatiris795@gmail.com
}

\begin{abstract}
This study was aimed at investigating written corrective feedback applied by an English teacher in writing class at eighth grade students of SMP NU Palangka Raya. Two research questions were formulated in this study. (1) How is the teacher written corrective feedback technique applied in English class of SMP NU Palangka Raya; (2) What are written feedback patterns applied by an English teacher in writing class at eighth grade students of SMP NU Palangka Raya.

This study was case study with qualitative approach. For the data collection, it was used the instruments such as observation equipped with observation checklist, interview equipped with interview guideline, documentation and field notes. To analyze the data, it was through the techniques: data collection, data display, data reduction, and conclusion/drawing. For the data endorsement, it was used triangulation technique. The results showed that the teacher applied written corrective feedback technique in the class by some steps. The written corrective feedback applied by the teacher focuses on correct word choice, punctuation, grammar, organization, spelling, and content. The teacher also used affective feedback which feedback in the form of motivation on teacher's writing. The patterns of written corrective feedback were feedback sandwich and gold star. Students' response through written corrective feedback applied were: (1) teacher written feedback was objective, (2) teacher written feedback was clear, (3) teacher written feedback assisted the students (4) teacher written feedback was encouraging. Keywords: Writing, teacher feedback, descriptive text
\end{abstract}




\section{INTRODUCTION}

Writing is intellectual and emotional exhibitionism. Regardless the form of a work, it reveals thoughts and values of its creator. Even with lies, exaggerations, and omissions, a researcher cannot hide his or her teaching process. The moment the first word is a record, the author becomes both powerful and vulnerable. When people read, they try to guess who an author is. Writing is one of four skills (reading, listening, speaking, and writing) which are to be mastered in learning English. In the academic task of students as second language learning, learners are required not only to be able to speak, to listen, and to read but also to be able to write. Writing is important for them to communicate the knowledge and thought a process like to make, examination, term papers and a job application (Rahmawati, 2009, p. 8).

Fauziati (2008, p. 147) states that as one of four language skills, writing always occupies a place in most English language course. One of the reasons is that more and more people need to learn to write in English for occupational or academic purposes. English department students especially need to learn to write and to prepare themselves for the final academic assignment thesis writing. Thus, in terms of students ${ }^{\text {ee }}$ needs, writing occupies an equal role with the other language skills. Although writing is very important, it is a difficult subject, especially for the student. The reason is that writing is a mixture of the idea, vocabulary, and grammar.

Feedback is an essential component of any English language writing course. Ur defines feedback as information that is given to the learner about his or her performance of the learning task, usually with the objective of improving their performance (Srichanyachon, 2012, p. 2). Besides, there are some kinds of text in English, such as exposition, argumentative, description and narration. Each text has different characteristics. There are generic social function, structure and lexicon grammatical features. Usually, the students can differentiate each text from another and they mix all kinds of texts. This was being a challenge for the teacher to find out how the student can distinguish each kind of text from another.

In SMP NU Palangka Raya, writing is one of the skill subjects that are learned by students on the first, second- and third-years grade students. The researcher discovered this fact because the researcher has taught at SMP NU Palangka Raya especially the eighth grade on teaching practice in the seventh semester ago. In this study, the researcher chooses descriptive text as a student'se genre problem in writing activity that needs to be improved because the students' writing problem was when they are making a text. According to the syllabus of SMP NU Palangka Raya, this kind of text is taught at the second grade of junior high school on the first term.

Anyhow, the problem of students ${ }^{\text {ee }}$ ability in writing was how to write appropriately. The problem will be solved by trying to find another strategy for teaching writing in order to make an effective learning writing process. It supposed to help students ${ }^{\text {ee }}$ writing, so it can increase their writing. Meanwhile, the main objective is to make the writing become easier to learn for the students.

Based on the statement above, the researcher is interested in analyzing the strategy that is used by an English teacher to improve students writing ability at the eighth grade of SMP NU Palangka Raya. The researcher did a preliminary study to 
make sure the strategy that uses by an English teacher, and the result of preliminary study are the teacher always use teacher feedback such as spoken feedback and written feedback to correct student writing product. In this study, the researcher just focuses on written feedback with conducted the study to investigated written feedback pattern that applied to an English teacher.

\section{LITERATURE REVIEW}

\section{Writing}

Writing is intellectual and emotional exhibitionism. Regardless the form of a work, it reveals thoughts and values of its creator. Even with lies, exaggerations, and omissions, a researcher cannot hide his or her thought process. The moment the first word is recorded, the author becomes both powerful and vulnerable. When people read, they try to guess who an author is (Rahmawati, 2019, p. 8).

Writing is one of four skills (reading, listening, speaking, and writing) which should be mastering in learning English. Writing is important for them to communicate the knowledge and thought a process like to make, examination, term papers, and a job application. Writing becomes a tool for international communication for people. In this form, the researcher expresses his/her ideas, experience, though, and feeling. Writing can also be used as means of communication. Through writing, the meaning conveys in writing form, and furthermore, it is a process of organizing thinking on writing a form to share the idea (Abrar, 2013, p. 12).

So, writing is an important skill for someone to tell an idea, fact, and information. The writing product will be expected to give the reader some information and to entertain the reader also. It should be perfect in order to make our writing product easy to understand by the readers then the readers.

\section{Teacher Feedback}

The teacher has been the main source of feedback both an oral or written language in many classes (Marlyn, 2002, p. 15). In many classes, the teacher is the sources of feedback. Indeed, the teacher is very helpful in facing some difficulties in their writing. The teacher helps them by giving some outlines of how to write well and check the content and the written mistakes.

According to Pratiwi (2013), the teacher can give feedback in the form of a question to ask for clarification or suggest expansion. Besides, the teacher may give remarks which reveal understanding towards students' composition, identify a mechanical problem in a specific sentence and/or give praise when students are working well in their writing. Those can be done to ensure the students that their written works are in line with the message they want to convey. After receiving feedback, the students could directly re-check and correct what mistakes they have done based on the teacher's correction. Commonly, the teacher corrects the students ${ }^{\text {ee }}$ writing one by one and then discusses it with the students face to face. It is called conferencing feedback. 
So, teacher feedback is the feedback given by the teacher in order to improve students writing skill and make the student writing product to be well. If student writing product is well, it will give information and entertainment to the readers.

\section{Descriptive Text}

Descriptive text is text that figures something clearly and specially. The descriptive text aims to figure or giving figures to something with one clear, so pretend readers get to see, hear, read or feel that thing described (Erlangga, 2017).

The descriptive paragraph is paragraph who tries to move the image, observing the result, and its feel to the reader. The writer tries to pass on character and all details of form which found on an object that was written by it. That thing purpose as to establish or enabling most composes it is imaginative or imagination to render it, so pretend readers see or feeling object own that spoken as a whole as one experienced by its the writer (Suparno, 2014).

\section{RESEARCH DESIGN}

Since the purpose of this study is to describe the language used in analytical This study used a qualitative approach. The design of the study was a case study. The researcher used this design to investigate written corrective feedback and the patterns applied in English class SMP NU Palangka Raya. The participants of this study were eighth grade students and the teacher were taken as a subject in this study. The researcher interviewed ten students and the English teacher of eighth grade at SMP NU Palangka Raya. The instrument in this study was the researcher herself who was considered as the key instrument. As said by Creswell (2012), the researcher herself who was present in the setting of the study was considered as the key instrument which was called as a human instrument. In this study, the researcher equipped herself with some research instruments consisting of observation, interview, field note, and documentation.

Data analysis was the process to arrange the data finding to make it comprehensible by collecting, arranging, coding, classifying, and grouping in order to make the research report. To analyze the data, the researcher did some procedures adopted from Nasution (2003, p. 126-130) which state there were four techniques used to analyze the data as follows:

Data Collection

The researcher has collected the data. The researcher collected the data from data collection was collected from observation, field note, interview, and documentation. Data collection consisted of observation to the school and the class during the study was being conducted; interviewed the students about their response or comment toward written corrective feedback that given by their teacher and interviewed the teacher about how was the teacher written feedback technique applied in English class of SMP NU Palangka Raya; made the field notes to record the data where it was not possible to collect data using observation or interview such as students atmosphere when they were revised writing product; documented students writing product, results of observation, results of interview, results of field notes and photos during research. 


\section{Data Reduction}

The data reduction on the study used by the researcher to reduce the appropriate data from data collection by filtering the important data based on the objectives of the study. In this study, all of the data gathered from the interview that covers how is the teacher written feedback technique applied and teacher's response. Data from observation about written corrective feedback applied by the English teacher and activity at eighth grade students. The documentation covers data in teacher's writing product, picture form, and visual information. All of the data processed based on the objective of the study.

Data Display

In data display, the researcher has reported the relevant data and confirms the study result. The researcher did data display with describing the result of data reduction in simple explaining using charts and tables. In this study, charts and tables described observation results; written corrective feedback mostly used by the teacher such as informational feedback, categories of feedback, and affective feedback. Starting from data collection to displaying data, was applied each time the researcher obtains data from the first session until the researcher can found a pattern of written feedback that applied by an English teacher.

\section{Verification}

The conclusions have been verified by looking back to the data reduction whether before, whiles or after data collecting. The researcher has concluded the result of study based on the problems and objectives of the study. Data based on the objectives of the study that investigate written corrective feedback applied by an English teacher on students ${ }^{\text {ee }}$ writing product and written corrective feedback pattern have summarized and verify by the researcher in answering the problems of the study. The data will be analyzed through systemic-functional approach in which the analysis of the data will be based on the clauses and its taxis (parataxis and hypotaxis) along with its logicosemantic relations.

\section{FINDINGS}

The researcher found the treatment that was applied by the teacher when she gave written corrective feedback to the students based on observation process. The researcher did observation three times. In the first observation, the researcher tried to investigate the strategy that used by an English teacher, and the result was the teacher always used written corrective feedback to correct student writing product. Second and third observation, the researcher observes teaching and learning process in the class when the teacher gave written feedback with the steps as follows:

a) The teacher explains about the text which will be made by the student, and then the teacher assigning the composition topically, normally brainstormed ideas with students.

b) The teacher assigning the students drawing their attention to relevant language structures and vocabulary related to the topic. After the assigning was clear, students produced single drafts. 
c) The student got an assignment to make a descriptive text about tourist attraction of Central Borneo.

d) The teacher collects students writing product (when the class ending).

e) The teacher analyzed teacher's error on their first draft and gives some error correction, comment and suggestions. The teacher gives error correction or marks such as underlining, circle, delete word and arrow.

f) The teacher also gave affective feedback on students writing which is used to motivate students on writing. Affective feedback is given such as "good", "nice", etc.

g) The teacher returns student writing product and ask them to revise their writing based on written corrective feedback given (next meeting).

h) The students revise their writing.

i) The students collect their final draft to the teacher.

When the researcher observes while the students were revising their writing, there were some students who felt so shame when they received their draft that has been corrected by the teacher and they got many mistakes some students laughed at them. It made the students more ashamed. Written corrective feedback had given was clear and understandable by the students. It can be shown that the students were able to rewrite their writing based on the teacher written feedback. It could be inferred that the students really needed to be written feedback to help them to revised their writing.

They tried hard to comprehend the written feedback given. They read and comprehended every feedback that showed their mistakes and also guidance to correct them. It made the students easier to revise their writing. It could be assumed that written feedback given by the teacher is encouraging.

By consulting the teacher's written feedback, the students were stimulated to make their work better. They were so enthusiastic to correct their mistakes. The teachers written feedback motivated the students to revise their writing. Most students are undisturbed by teacher written feedback in their writing process. They looked enthusiasm when they revised their work. They did not feel disturbed because the teacher corrected without changing the main idea.

To find out the written corrective feedback pattern applied by an English teacher, the researcher documented the students ${ }^{\text {ee }}$ writing product which has been already given feedback by the teacher. After analyzing students ${ }^{\text {ee }}$ writing product, the researcher found the patterns of written corrective feedback applied on students writing.

The first pattern was feedback sandwich. Feedback sandwich was the form of positive feedback. The teacher never gave negative comments on students writing. The teacher always starts and end with positive feedback, sandwiching suggestions for improvement between these reinforcing comments. The feedback sandwich on teacher's writing applied by the teacher such as "please add more details about ..." and "please describe tangkiling more" . The teacher gave that comment if the students writing still not good or just made a text in some lines. The impact of gave feedback sandwich on students writing were motivate the students to improve their writing. When the students got written corrective feedback, commonly students felt down or give up on writing, they think that they could not write well because their writing was 
incorrect and have many error correction from the teacher. So that, the teacher make it balance with positive comments on students writing to motivate the students on revising their writing.

The teacher also used gold star pattern on her feedback. It se mean that the teacher always praises the students writing to improve their writing motivation.

But the teacher just gives praise to comment on teacher's writing product, not publicly. The teacher gave this pattern if the students success in their writing.

The teacher did not give the students ${ }^{\text {ee }}$ mistakes but also a correct form for students such as word choice, grammar, punctuation, morpheme, and deleted word. To get the results, the total number of teacher written feedback on each student composition was counted. Then how much feedback in the form of direct and indirect feedback was counted. Also, the amount of affective feedback was counted. The last step was counting the percentage are presented below.

Table

Informational Feedback

\begin{tabular}{|l|l|l|l|}
\hline No & Informational feedback & Total & Percentage (\%) \\
\hline 1 & Direct Feedback & 72 & $71.2 \%$ \\
\hline 2 & Indirect Feedback & 29 & $28.8 \%$ \\
\hline & Total writing & 101 & $100 \%$ \\
\hline
\end{tabular}

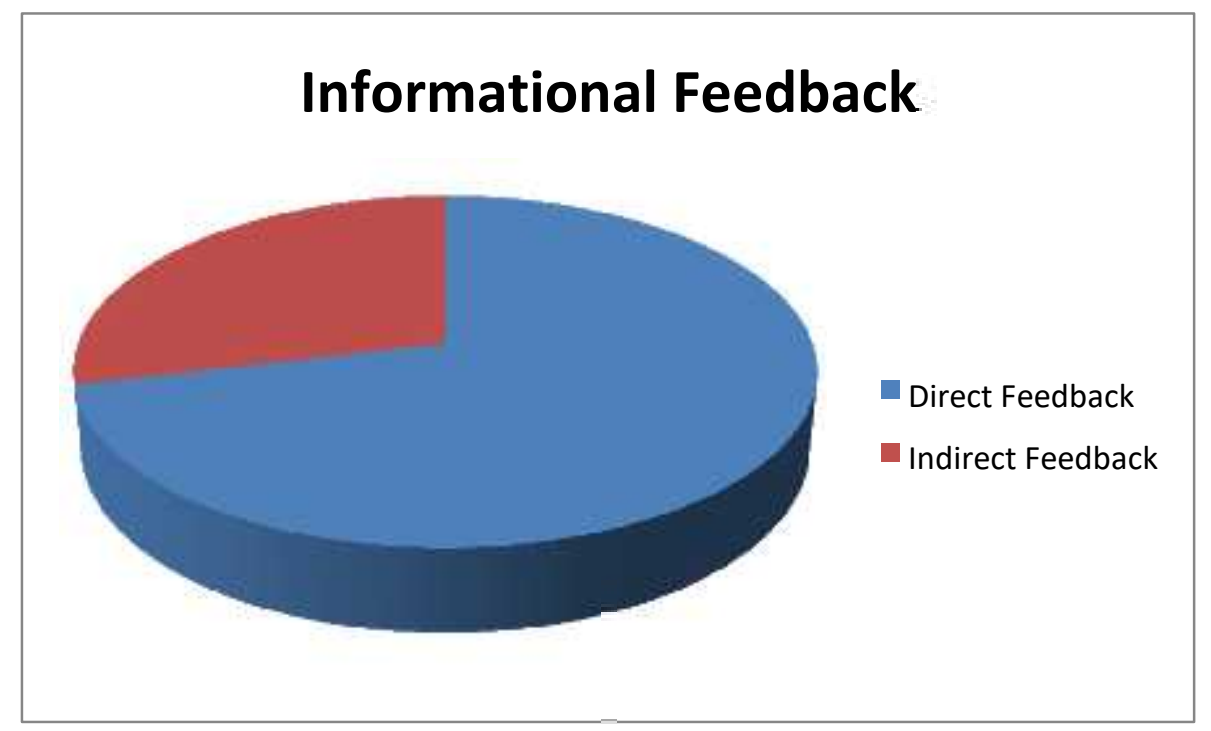

Figure 
Table 4.2 shows that and $71.2 \%$ the teacher using direct feedback $28.8 \%$ using indirect feedback. The teacher common gives feedback using direct feedback. Direct feedback refers to a teacher providing a correct linguistic form for students (e.g., word, morpheme, phrase, rewritten sentence, deleted word or morpheme).

The researcher analyzed teacher's work to get the categories of the teachers written feedback. The teacher corrects on students' mistakes such as:

a) Organization

It's means that the arrangement of ideas or details in a perceptible order in a paragraph.

b) Punctuation

It's mean that the set of marks used to regulate texts and clarify their meanings, principally by separating or linking words, phrases, and clauses. c) Spelling

The process or activity of writing or naming the letters of a word.

d) Word choice

An act of choosing between two or more possibilities. It's means that there was some word that has same definition but different meaning. So, the students should choose the word that the meaning suitable with the sentence.

e) Grammar

The whole system and structure of a language or of languages in general, usually taken as consisting of syntax and morphology and sometimes also phonology and semantics.

f) Content

It focuses on paragraph coherence, meaning, and purpose. The students should make a text with good content.

Table

Categories of Feedback

\begin{tabular}{|l|l|l|l|}
\hline No & Categories & Total & Percentage \\
\hline 1 & Organization & $\mathbf{1 2}$ & $\mathbf{5 , 1} \%$ \\
\hline 2 & Grammar & $\mathbf{4 2}$ & $\mathbf{1 8 \%}$ \\
\hline 3 & Word choice & $\mathbf{1 1 8}$ & $\mathbf{5 0 , 7} \%$ \\
\hline 4 & Punctuation & $\mathbf{4 6}$ & $\mathbf{1 9 , 8} \%$ \\
\hline 5 & Spelling & $\mathbf{1 0}$ & $\mathbf{4 . 3} \%$ \\
\hline 6 & Content & $\mathbf{5}$ & $\mathbf{2 , 1} \%$ \\
\hline
\end{tabular}




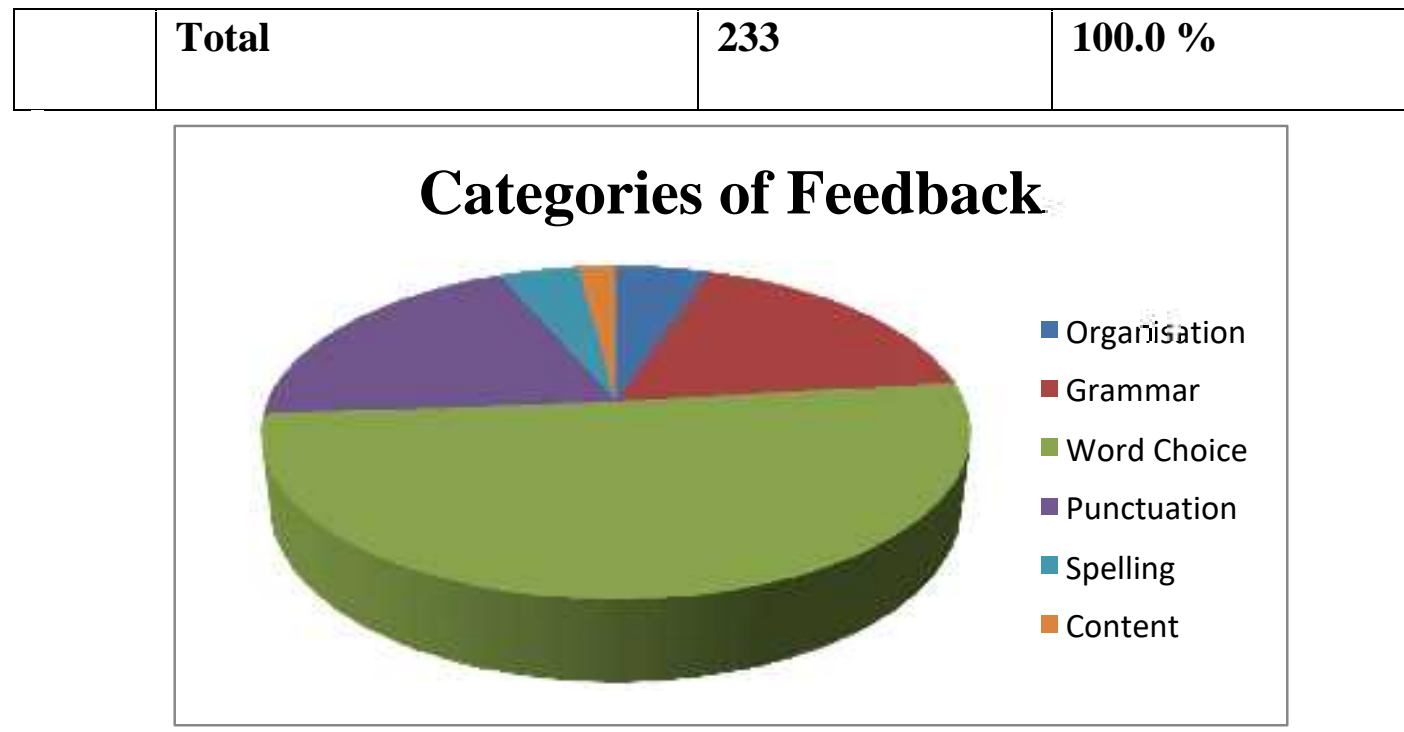

Figure

Categories of feedback

Table 4.3 shows that $50.7 \%$ teacher's written feedback focuses on word choice, 19.8 $\%$ punctuation, $18 \%$ grammar, $5.1 \%$ organization, $4.3 \%$ spelling,

$2.1 \%$ content. The teacher common gives feedback on students ${ }^{\text {ee }}$ word choice. The mistaken of word choice by students such as users (visitors), delicious (nice), maintained (protected) etc.

The teacher explains why she focuses on word choice. It is because the main problem that faced by the students was lack of vocabulary. So, the teacher would to focuses on word choice first, because the word was the main component to make a text or paragraph. The teacher did not pay attention to the organization because the students so many made mistakes on word choice, they would be understood with the organization if they have been a success on word choice.

The teacher also used affective feedback which feedback in the form of motivation on teacher's writing. To get the result, the total number of teachers written feedback on each teacher's composition was counted.

Table

Affective feedback

\begin{tabular}{|l|l|l|l|}
\hline No & Affective feedback & Total & Percentage (\%) \\
\hline 1 & Containing & 16 & $64 \%$ \\
\hline 2 & Not containing & 9 & $36 \%$ \\
\hline & Total writing & 25 & $100 \%$ \\
\hline
\end{tabular}




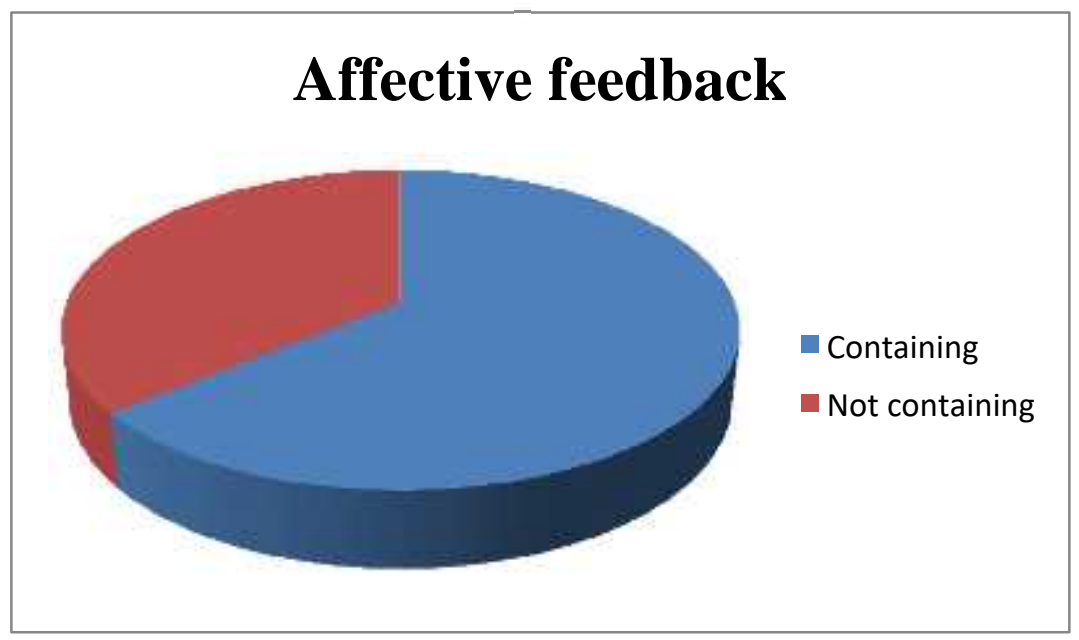

Figure 4.3: Affective Feedback

Table 4.4 shows that $64 \%$ of teacheres written feedback contains affective feedback and $36 \%$ of teachere's written feedback does not contain affective feedback. It means that the written feedback mostly contains some comments to strengthen students' positive emotion. The teacher provides praise in their feedback such as "good", "nice" etc.

\section{DISCUSSION}

In giving written corrective feedback the teacher analyzes the teacher's first draft in simple ways. The teachers analyze teacher's error on their first draft and give some error correction, comment, and suggestions. The teacher gives error correction or marks such as underlining, circle, delete word and arrow.

From the results, the researcher found the pattern of written corrective feedback applied on students writing. The first pattern was feedback sandwich. Feedback sandwich was the form of positive feedback. The teacher never gave negative comments on students writing. The teacher always starts and end with positive feedback, sandwiching suggestions for improvement between these reinforcing comments. The feedback sandwich on teacher's writing applied by the teacher such as "please add more details about ..." and "please describe tangkiling more". The teacher gave that comment if the students writing still not good or just made a text in some lines. The teacher takes tone that giving a suggestion for improvement, not just condemning such as give good sentences on comments rather than "This is bad" or etc.

The teacher commonly used same feedback to all of the students. The teacher was not differentiated feedback. Also, the teacher used gold star pattern on her feedback. It's mean that the teacher always praises the students writing to improve their writing motivation. But the teacher just gives praise to comment on teacher's writing product, not publicly.

The teacher giving written corrective feedback using mark or error codes, comment, and suggestion. When the teacher using mark or error codes, she common giving marks on word choice. It is suitable with the theory from Cohen cited in Pratiwi (2013) 
which stated that in written feedback, comments, correction and/or marks was applied to students ${ }^{\text {ee }}$ written work draft.

\section{CONCLUSION}

On teaching using written corrective feedback, the teacher did some steps as follows: explain about the text which will be made by the student, and then the teacher assigned the composition topically, normally brainstormed ideas with students. The teacher assigned the students drawing their attention to relevant language structures and vocabulary related to the topic and then the students produced single drafts. When the students collect their writing, the teacher gave feedback on their writing. The teacher used simple ways on giving written corrective feedback. The teacher analyzed student's error on their writing and gives some error correction, comment and suggestions. The teacher gives error correction or marks such as underlining, circle, delete word and arrow. The teacher also gave affective feedback on students writing which is useful to motivate students on writing. Affective feedback is given such as "good", " nice", etc.

The pattern of feedback used was feedback sandwich. The teacher never gave negative comments on students writing. The teacher always starts and end with positive feedback, sandwiching suggestions for improvement between these reinforcing comments. The impact of giving feedback sandwich on students writing was motivate the students to improve their writing. When the students got written corrective feedback, commonly students felt down or give up on writing, they think that they could not write well because their writing was incorrect and have many error correction from the teacher. So that, the teacher make it balance with positive comments on students writing to motivate the students on revising their writing. The teacher also used gold star pattern on her feedback. It's mean that the teacher always praises the students writing to improve their writing motivation. The teacher gave this pattern only if the students success in their writing.

\section{REFERENCES}

Abrar, M. (2013). The Students' Strategies in Writing Descriptive Text at The Tenth Grade of SMAN 1 Mentaya Hilir Selatan Samuda. Unpublished Thesis. Palangka Raya: IAIN Palangka Raya.

Akiah, S.S \& Ghazali, Z. (2015). The Effects of Teacher And Peer Corrective Feedback On The Grammatical Accuracy In Writing Among The L2 Learners, Skop: Komunikasi dan Pendidikan, 2: 155

Amato, M., Example of Editing and Revising on journal http://ww2.valdosta.edu/ troot/eced4300/Proofreader's\%20Marks\%20for \%20Revision\%20\&\%20Editing\%20\%28color\%29.pdf Arizona Working Papers in SLA \& Teaching, 15: 65-79.

Berewot, J. (2001). The effectiveness of Teacher's Written Feedback in Developing Grammatical Mastery of the English Passive Voice of the Third Grade 
WRITTEN CORRECTIVE FEEDBACK APPLIED BY ENGLISH TEACHER AT THE EIGHTH GRADE STUDENTS OF SMP NU PALANGKA RAYA

Students of SLTP STELLA DUCE 1 Yogyakarta. Published Thesis. Yogyakarta: Sanata Dharma University Yogyakarta.

Bijami, M., Kashef, S. H., \& Nejad, M. S.(2013). Peer Feedback in Learning English Writing: Advantages and Disadvantages. Journal of Studies In Education. Malaysia: Macrotink Institute, 3(4): 92-93.

Binglan, Z. \& Jia, C. (2010). The Impact of Teacher Feedback on The Long-Term Improvement in The Accuracy of EFL Student Writing. China: University of Science and Technology of China.

Brown, D. H. (2011). Teaching by Principles: An Interactive Approach to LanguagePedagogy, Inc.

Burnett, P. C. \& Mandel, V. (2010). Praise and Feedback in the Primary

Classroom: Teachers ${ }^{\text {ee }}$ and Students ${ }^{\text {ee }}$ Perspectives. Australian Journal of Educational \& Development Psychology, 10(1): 8.

Burnett, P. C. (2010). Praise and Feedback in the Primary Classroom: Teachers ${ }^{e e}$ and Students ${ }^{\text {ee }}$ Perspectives, Australia: vol,

Creswell, J.W. (2012). Educational Research: planning, conducting, and evaluating quantitative and qualitative research $\left(4^{\text {th }} E d\right)$. Nebraska: University of Nebraska.

Eckstein, J., Bergin, J., Sharp, H. (2002). Patterns for Active Learning.

Ellis, R., Loewen, S., \& Erlam, R. (2006). Implicit and Explicit Corrective Feedback and the acquisition of L2grammar. Studies in Second Language Acquisition. 28: 339-368.

Fauziati, E. (2008). The teaching of English As A Foreign Language (TEFL), Surakarta: Muhammadiyah University Press.

Ferris, D. (2004). The "Grammar Correction" Debate in L2 Writing: Where are, and where do we go from here? (and what do we do in the meantime...?). Journal of 11th Language Writing, 13: 49-62.

Gibbs, G. \& Simpson, C. (2004). Conditions Under wich Assessment Supports Students ${ }^{\text {ee }}$ Learning. Learning and teaching in higher education. 1: 3-31.

Graham, S. \& Perin, D. (2007). Writing Next: Effective Strategies to Improve Writing of Adolescents in Middle and High Schools. New York: Alliance for Excellent Education.

Harmer, J. (2001). The Practice of English Language Teaching. London: Longman.

Hartatie, E. (2016). The Effectiveness of Teacher Feedback Technique Toward Students' Ability in Writing Recount Text at SMA-N 1 Katingan Tengah. Unpublished Thesis. Palangka Raya: IAIN Palangka Raya.

Hattie, J. \& Timperley, H.(2007). The Power of Feedback. American Educational Research Association, 77(81).

Hayland, K. (2006). Teaching and Researching. London: Longman.

Hornby, A. S. (2002). Oxford Advanced Learner's dictionary. New York: Oxford University Press.

Jack, R. \& Willy, R. (2002). Methodology in Language Teaching. Cambridge: Cambridge University press. 
WRITTEN CORRECTIVE FEEDBACK APPLIED BY ENGLISH TEACHER AT THE EIGHTH GRADE STUDENTS OF SMP NU PALANGKA RAYA

Karim, M. Z. \& Ivy, T. I. (2011). The Nature of Teacher Feedback In Second Language (L2) Writing Classrooms: A Study On Some Private

Universities In Bangladesh, Bangladesh: Presidency University

Kawedar, B., Marini, A., Trinitas, M., Wati, R. (2018). Materi Ajaran Kelas X". Muara Teweh.

Lee, I. (2008) Student Reactions to Teacher Feedback in Two Hong Kong Secondary Classrooms. Journal of Second Language Writing, 17: 144-16.

Lewis M. (2002). Giving Feedback in Language Classes. The University of Auckland: SEAMO Regional Language Centre.

Liu Y. (2008). The Effects of Error Feedback in $11^{\text {th }}$ Language Writing.

Magno, C. \& Amarlis, A. M. (2011). Teacher's Feedback Practices in Second Language Academic Writing Classrooms, Manila: De La Salle and Philippine Universities.

Marylin, L. (2002). Giving Feedback in Language Classes. Auckland: The University of Auckland.

Miftah, M. Z. (2012). Improving The Tenth-Years Students Writing Ability at MA Mambaus Sholihin Gresik Through Mind Mapping. Lingua Jurnal Ilmu Bahasa dan Sastra, 5(1): 189-191.

Miftah, M. Z. (2015). Peer Response in an Indonesian EFL Writing Class: A Case Study. Proceeding of ICERD, 633-644.

Miftah, M. Z.(2015). Enhancing Writing Skill Through Writing Process Approach. Journal of English as a Foreign Language, 5(1): 20-21.

Mulyaningsih, D. U. (2013). An Analysis of Students "e Ability in Writing Descriptive Texts. Journal of English and Education, 1(2): 16-22.

Oshima, A. \& Hogue, A. (2017). Introduction to Academic Writing ( $3^{\text {rd }}$ Ed.). : Pearson Education Inc.

Pratiwi, W. D. (2013). Students ${ }^{\text {ee }}$ Perception Towards Teacheres Written Feedback among 11th Grade Students at SMAN 1 Wedi Klaten.

Rahmawati, L. (2019). Improving the English Graders' Ability of Writing Recount Texts Through the Process Writing Strategy at MTsN Grogol Kediri, Unpublished Thesis. Kediri

Reid, J. (2011). Writing: in the Cambridge guide to teaching English to speakers of other languages. Cambridge: Cambridge University Press.

Ryoo, M. L. (2014). The Effects of Teacher Feedback on EFL Students ${ }^{\text {ee }}$ Writing in a Korean University Class. The Journal of Asia TEFL, 1(1): 115.

Sabarun. (2011). Improving Writing Ability Through Cooperative Learning Strategy. Journal On English As A Foreign Language, 1(1): 41-44.

Siriluck, K. C. (2018). The Impact of Different Types of Teacher"es Written Feedback on EFL University Students" Writing. KKU Res J (GS), 8(2).

Srichanyachon, N. (2012). Teacher Written Feedback for L2 Learners "e Writing Development. Silpakorn University Journal of Social Science, Humanities, and Art, 12(1): 2.

Sugiyono. (2008). Metode Penelitian Kuantitatif Kualitatif dan R\&D. Bandung: Alfabeta. 
WRITTEN CORRECTIVE FEEDBACK APPLIED BY ENGLISH TEACHER AT THE EIGHTH GRADE STUDENTS OF SMP NU PALANGKA RAYA

Wen, Y. (2013). Teacher Written Feedback on L2 Students Writings. Jounal of Language Teaching and Research, 4(2): 427. 